\title{
Embryonic Sexing in Rabbits by Using Special Diet and Change of Vaginal PH
}

\author{
Sajad S. Shelan ${ }^{1}$, Asmaa Sh. Alilawy ${ }^{2}$ \\ College of Veterinary Medicine, Department of Surgery and Obstetric, Basra University, Basrah, Iraq
}

\begin{abstract}
This study was undertaken to investigate the effect of diet and Chang of vaginal pH on Sex ratio in different groups and biochemical parameters in pregnant does, . A total of 15 rabbits. Relied on the program (Diet +intra vaginal washing+ Time of copulation) Divided into three groups, Group I: 5 pregnant females supplied with drinking water mixed with sodium and potassium , Group II: 5 pregnant females supplied with drinking water mixed with calcium and magnesium, and Group III: 5 pregnant females (control) supplied with drinking pure water without any added. The study involved rabbits Weight of 2.5-3 kg at the age of about (9 months). Blood samples were collected from pregnant does in different groups. It was found that the delivering off springs male to female ratio were 10.7:1-0.4:1and o.7:1 for the first, second and third groups respectively. Also, yields maximum numbers of offspring males in $(\mathrm{Na}, \mathrm{K})$ group was(91.42\%).Also, yields minimum numbers of offspring females in Na and $\mathrm{K}(8.57 \%)$.while rabbits fed with $\mathrm{Ca}$ and $\mathrm{Mg}$ yields (27, 5\%) female pregnant does with Ca and $\mathrm{Mg}$ yield lowest numbers of offspring in males (27, 5\%).but yields maximum number in females(72.5\%).was higher than the male offspring in control group (40\%) and also male offspring of mothers $(\mathrm{Ca}, \mathrm{Mg})(27,5 \%)$ was lower than the male offspring in control group (40\%). Our results suggest that different amounts of ions in the diet of rabbits can have significant effect on the sex ratio of delivered rabbits offspring.
\end{abstract}

Keyword: Embryonic sexing, Diet, Physiological vagina

\section{Introduction}

The reproductive tract of the rabbit doe is bipartite from the ovary to the vagina. The vagina of New Zealand does is about $14-19 \mathrm{~cm}$ long. The urethral orifice opens into the vagina about $6 \mathrm{~cm}$ proximal from the introit us (Wingerd, 1984). Immediately proximal to this orifice there is a translucent crescent-shaped tissue that forms a "valve-like" structure named the urethro vaginal sphincter (Noyes et al., 1958).

The distal and proximal sections of vagina are named uretro vagina and cervico vagina, respectively (Jequier, 2006). Each no gravid uterine horn is 13 to $14 \mathrm{~cm}$ long, and the complete oviduct (ampulla plus isthmus) is of similar length. The bipartite arrangement in rabbits prevents embryos from migrating from one uterus to the other, as can occur in species with a bicornuate uterus. It is very important to understand that :1) the female rabbit ovulates (produces eggs) in response to stimulation of mating; 2) ovulation occurs about ten hours after mating; 3) the sperm that is deposited in the female at the time of mating is very large in number compared to the ovum (eggs) that are ovulated by the female; and, 4) the sperm is not capable of fertilizing the ovum until they have matured at least six hours in the female reproductive tract and that the sperm live a relatively long period of time as compared to the egg. Rabbits do not have cyclic reproductive stages. Therefore, it is suspect that the vaginal environment in precoital rabbits is comparable to that during diestrus or anestrus in mice, rats, hamsters, and dogs (Noguchi et al., 2003) . Ovulation rate is the total number of ova shed by the ovaries at ovulation. In rabbits, ovulation is induced by the coitus stimulus. The coitus leads to a nervous stimulus that induces release of the gonadotropin-releasing hormone $(\mathrm{GnRH})$ in the hypothalamous. This hormone activates the synthesis and secretion of the follicle-stimulating hormone (FSH) and the luteinizing hormone ( $\mathrm{LH})$ at the anterior pituitary gland. The
FSH is known to be very important for the terminal growth of the follicles, while an acute rise in LH triggers ovulation (Rosell, 2000). Vaginal $\mathrm{pH}$ The optimal vaginal $\mathrm{pH}$ to maintain sperm viability and motility ranges from 7.0 to 8.5 . (Kelly, 1990)1, 2 In fact, a reduction in sperm motility is seen at vaginal $\mathrm{pH}$ of less than 6.0. The alkaline $\mathrm{pH}$ of semen protects sperm temporarily. However, reduction in semen volume and/or decreased alkaline seminal vesicular secretion may negatively impact fertility since buffering capacity of semen against vaginal acidity becomes inadequate. (Brannigan and Lipshultz, 2008). $\mathrm{pH}$, is the standard measure of hydrogen ion concentration, the quantitative appraisal of the acidity or alkalinity of a solution. Numerically, it is equal to 7.0 for neutral solutions. Levels of $\mathrm{pH}$ less than 7.0 characterize acidic solutions, while levels greater than 7.0 characterize basic (or alkaline) solutions. The vaginal $\mathrm{pH}$ fluctuates from 3.8 to 4.5 , and is classified as moderately acidic.( Kelly , 1990) The fluid content of the vagina is derived from:

1) Mucus secretions of the cervical columnar cell.

2) Transudation through the vaginal walls.

3) Vulvar secretions originated from sebaceous and sweat glands.

4) Mucus secretion of Bartholin's glands.

5) Substances produced by microorganisms present in the vagina.

(Lepargneur and Rousseau, 2002). The gestation period is the amount of time necessary for the development of the new individual within the uterus - the time period from conception to birth (kindling)( Berepudo et al., 1993). The gestation period in a domestic rabbit is normally twentyeighth thirty-two days. Most does kindle at approximately thirty to thirty-one days after mating. This can vary from twenty-four to forty-eight hours in individual strains with a given breed. Pregnancies that geminate (end) earlier than twenty seven days; and, after fourteen days, with the passing of an undeveloped and/or partially degenerated feti is termed an abortion(Boiti , 2004). Demonstrated an altered sex ratio

Volume 6 Issue 1, January 2017 


\section{International Journal of Science and Research (IJSR) \\ ISSN (Online): 2319-7064}

Index Copernicus Value (2015): 78.96 | Impact Factor (2015): 6.391

in the offspring of rabbit in relation to the $\mathrm{pH}$ of the vagina at the time of mating. When the cervical $\mathrm{pH}$ value was 6.5 to 7.3, there was a predominance of female. There was difference in sex ratio with a $\mathrm{pH}$ value from 7.3 to 7.5 . Values of $\mathrm{pH}$ from 7.5 to 8.3 produced more males. However, (Suarez and Pacey, 2006) suggested that a very alkaline seminal fluid favor males and a very acid vagina would favor females. (Roy et al. , 2004) studied the relationship between sex ratio and vaginal $\mathrm{pH}$ at certain times of mating. They found significant negative correlation between vaginal $\mathrm{pH}$ and sex ratio of subsequent litters when mating occurred during midestrus. They concluded that fluctuations in vaginal $\mathrm{pH}$ may differentially affect longevity, motility, or fertilizing capacity of X-and Y-sperm and/or may reflect other physiological changes in the female which occur over the receptive period. sodium bicarbonate prior to artificial insemination. He obtained no offspring at $\mathrm{PH}$ from 3.8 to 5.1, 29 males and 35 females at $\mathrm{pH}$ from 5.6 to 6.2 and 20 males and 23 females at $\mathrm{pH}$ from 7.9 to 9.2. Using other parameters for determination sex ratio. (Sharif and Olufowobi, 2006).

\section{Materials and Methods}

\section{Animals \\ A total of 15 domestic mature female rabbits were used in this study. weighting 2.5 to $3 \mathrm{~kg}$ (9 months old) were purchased from Prior to their use all rabbits were housed individually from two to three weeks in stainless steel cages at a room temperature of $20 \pm 1^{\circ} \mathrm{C}$ with 12 hours of light per day. Animals were fed rabbit diet .}

\section{Types of fed rabbit diet}

A suggested food analysis for adult pet rabbits is summarized in Box

Fat: $1-4 \%$

- Calcium (Australia): 0.6-1.0\%

- Sodium (Indian ):0.25-0.5\%

- Vitamin A: 10 000-18 $000 \mathrm{IU} / \mathrm{kg}$

- Vitamin E: 40-70 mg/kg

- Trace elements: Magnesium 0.3\% (UK), Potassium 0.6$0.7 \%$ (Indian)

\section{Nutritional value For pregnant rabbits \\ Calcium =carrots; celery; lettuce \\ Magnesium=Potatoes small amounts; cooked tomatoes; Bran Bread \\ Potassium $=$ broccoli; corncobs \\ Sodium=sodium chloride (Salt)}

Tree leaves can be eaten by rabbits, especially from fruit trees

Fetuses from pregnant White does were studied at 30 days of gestation (day of ovulation $=7-10$; day of mating $=7$; term = 31 days), Pregnancy All does were mated twice whenever possible. Forced mated was performed if the doe refused to accept the buck. Ten days after mating, does were palpated to detect pregnancy. Doe that failed to conception was subjected to mating again with a buck randomly chosen in the same day of palpation. Afterward we test the pregnancy of doe in 10th and 14th day after the mating by the one of two methods. The preferred method is to pal 12 ower abdomen of the doe by the thumb and forefinger checking for nodules about the size of a marble. The other method is not only more risky but also more inaccurate. The other method is to mate the doe with the buck again. This can cause problems because the doe has two uterine horns, each of which can carry babies. It is possible for one horn to be fertilized on the first mating and the second to be fertilized on the second mating (Mousa-Balabel , 2004)

\section{Experimental Design}

Use of fifteen females rabbits divided into three groups. Diet +intra vaginal washing+ Time of copulation.

Group I: 5 pregnant females supplied with drinking water mixed with $1 \%$ sodium and potassium (Zsolt Szendrő et al ., 2011)

Group II: 5 pregnant females supplied with drinking water mixed with $1 \%$ calcium and magnesium (Zsolt Szendrő et al ., 2011).

Group III: 5 pregnant females (control) supplied with drinking pure water without any added.

\section{Blood Chemistry}

Blood samples were collected three times from all the does (within 0.5 to $1 \mathrm{~h}$ directly before mating, at day 15 and day 25 of pregnancy) to collect blood by cardiac puncture in. vacationer tubes and were centrifuged for 20 minutes at $3000 \mathrm{rpm}$ to obtain the serum which was kept in a refrigerator $\left(-20 \mathrm{C}^{\circ}\right)$ until analysis. The animals were prevented to eat for some hours before blood sampling.until anslyzed for the calcium and Magnesium, serum calcium concentrations were estimated using the calcium Kit (Accent 200, china, cat.No.7-247).serum Magnesium concentrations were estimated using the Magnesium Kit (Accent 200, china, cat .No.7-229). serum sodium and potassium concentrations were estimated using Kit .Each of these tests worked by device chemistry automatic analyzeraccent 200 system

\section{Chang of vaginal pH by Sodium bicarbonate}

Sodium bicarbonate (IUPAC name: sodium hydrogen carbonate) is a chemical compound with the formula $\mathrm{NaHCO}_{3}$. It is a salt composed of sodium ions and bicarbonate ions. Sodium bicarbonate is a white solid that is crystalline but often appears as a fine powder. It has a slightly salty, alkaline taste resembling that of washing soda (sodium carbonate). (Arm and hammer, 2009). Sodium bicarbonate can be used as a wash to remove any acidic impurities from a "crude" liquid, producing a purer sample. Reaction of sodium bicarbonate and an acid produce a salt and carbonic acid, which readily decomposes to carbon dioxide and water (Orcutt, $\boldsymbol{J A}, \mathbf{2 0 1 2}$ ):

\section{Measurement of vaginal $\mathrm{pH}$}

Measurement of vaginal $\mathrm{pH}$ was accomplished by inserting a small diameter combined glass electrode $(\mathrm{pH}$ electrode and reference electrode) into the vagina immediately after mating. Readings were taken using a standard $\mathrm{pH}$ meter.

\section{Statistical Analysis}

The data were analyzed on the basis of one way ANOVA and independent T-test by using SPSS (Special Program for Statistical System) version 9.0. All data are expressed as

\section{Vc Issue 1, January 2017




\section{International Journal of Science and Research (IJSR) \\ ISSN (Online): 2319-7064}

Index Copernicus Value (2015): 78.96 | Impact Factor (2015): 6.391

mean \pm S.D . (using a significant level of $P \leq 0.05$ ). (Steel and Torrie, 1980)

\section{Results and Discussion}

\section{Sex Ratio}

There are many method for sex determination, that among them specific diet could be the method of choice because of its simplicity, low expenses and the public approval .The American society for Reproductive medicine has ruled that it is proper and ethical to help couples to choose thesex of their babies(Gottlieb, 2001). Our results suggest that different amount of ions in the diet of rabbits can have significant effect on the sex ratio of delivered rabbits .It babies it seems that relative excess of sodium and potassium ions in the diet would favour the birth of males. While relative excess of calcium and magnesium ions in the diet would favour the birth of females (see images 1). If mineral imbalance in the diet the female before fertilization effects the sex ratio of the pregnancy (Bolet et al., 1982). These results show that sodium and potassium diet is in favour of male birth, which is similar to our results. It was found that, in the first group mothers $(\mathrm{Na}, \mathrm{K})$, all of the 5 rabbits became pregnant which delivered 35 offspring. Their gender was 32 male $(91.42 \%)$ and 3 female $(8.57 \%)$. In the second group, $(\mathrm{Ca}, \mathrm{Mg})$, all of the 5 rabbits became pregnant and delivered 40 offspring, their gender was 11 male $(27,5 \%)$ and $29 \mathrm{female}(72.5 \%)$ and in the third group, drinking pure water without any added. All five rabbits became pregnant and delivered 25offspring that 10 male (40\%) and 15female $(60 \%)$. The sex ratio of female to male in the first group $(\mathrm{Na}$ $, \mathrm{K})$ and in the second group $(\mathrm{Ca}, \mathrm{Mg})$ were 10.7:1-0.4:1, while this ratio in the third group drinking pure water without any added. was o.7:1 respectively (Figure1). The percentage of the male offspring of mothers $(\mathrm{Na}, \mathrm{K})$ $(91.42 \%)$ was higher than the male offspring in control group (40\%) and also male offspring of mothers $(\mathrm{Ca}, \mathrm{Mg})$ $(27,5 \%)$ was lower than the male offspring in control group (40\%) (Figure1). Similar findings were reported by Krackow examined the effects of timing of mating and crowding of pregnant females on litter sex ratios in mice .Females either copulated during periods when on other females to the mating unit copulated simultaneously (single mating condition ) or When more than one females were placed individual caged after mating (isolated condition )or they remained in the group until shortly before littering (crowded condition ).The results showed a reduced sex ratio variance under single mating and crowded condition (Krockow, 1997). Last medical technique that can be used to select for sex is sperm sorting. New technologies allow sperm to be sorted into those carrying $\mathrm{X}$ or $\mathrm{Y}$ chromosomes with varying degrees of accuracy. To date, the most successful way in which to sort sperm is flow cytometry, which has been branded as the Micro Sort technique Sex selection using flow cytometry results from distinguishing between the identifiable differences between the $\mathrm{X}$ and $\mathrm{Y}$ chromosomes, as the $\mathrm{X}$ chromosome is larger than the $\mathrm{Y}$. The sorted sperm is then used to artificially inseminate the woman. Studies have shown that the Micro Sort technique is more effective in selecting for girls, a success rate of $91 \%$, than for boys, with a success rate of only $76 \% .12$ Sperm sorting appears, then, to be the least invasive and agreement with ( $S$ Chandraju, 2011). nutrition of parents decide the sex determination of the offspring (Baroiller and Cotta, 2001). the proportion of males is higher at an acidic $\mathrm{pH}$ (4.5) (Eggert, 2004).

Table 3.1: Sex ratio in different groups of Rabbits

\begin{tabular}{|c|c|c|c|c|c|c|}
\hline Groups & $\begin{array}{c}\text { Total no of } \\
\text { offspring }\end{array}$ & $\begin{array}{c}\text { No. of male } \\
\text { offspring }\end{array}$ & $\begin{array}{c}\% \text { age of male } \\
\text { offspring }\end{array}$ & $\begin{array}{c}\text { No. of female } \\
\text { offspring }\end{array}$ & $\begin{array}{c}\% \text { age female } \\
\text { offspring }\end{array}$ & $\begin{array}{c}\text { Sex } \\
\text { ratio }\end{array}$ \\
\hline Control & 25 & 10 & $40 \%$ & 15 & $60 \%$ & 0.7 \\
\hline$(\mathrm{Na}, \mathrm{K})$ & 35 & 32 & $91.42 \%$ & 3 & $8.57 \%$ & 10.7 \\
\hline$(\mathrm{Ca}, \mathrm{Mg})$ & 40 & 11 & $27,5 \%$ & 29 & $72.5 \%$ & 0.4 \\
\hline
\end{tabular}

\section{Blood Biochemical Findings}

The levels of biochemical are presented in Table 2. The concentrations of were significantly $(p \leq 0.05)$ increased in the Sodium and Potassium pregnant group(151.80 \pm 2.04 $\mu \mathrm{mol} / \mathrm{L}, \quad 3.01 \pm 0.7 \mu \mathrm{mol} / \mathrm{L})$ suspected males(91.42\%) compared with Calcium and Magnesium pregnant $\operatorname{group}(108.80 \pm 15.27 \mu \mathrm{mol} / \mathrm{L}, \quad 1.10 \pm 0.06 \mu \mathrm{mol} / \mathrm{L}) \quad$ suspected males $(27,5 \%)$, while The concentrations of were significantly $(\mathrm{p} \leq 0.05)$ increased in the Calcium and Magnesium pregnant group $(1.11 \pm 0.11 \mu \mathrm{mol} / \mathrm{L}, 4.68 \pm 0.39$ $\mu \mathrm{mol} / \mathrm{L})$ suspected female $(72.5 \%)$ compared with Sodium and Potassium $(0.60 \pm 0.17 \mu \mathrm{mol} / \mathrm{L}, 3.14 \pm 0.13)$ suspected female $(8.57 \%)$ (Figure1). were not in agreement with the reported by (Fregly MJ, 1981; Karr-Dullien and Bloomquist E., 1979) high sodium level from high-salt dams had significantly. No developmental effects were observed in the offspring of pregnant mice, rats, or rabbits given oral doses of sodium chloride equivalent to 189,147 , and $147 \mathrm{mg}$ of sodium ion per $\mathrm{kg}$ of body weight, respectively, on days 6-15 (mice and rats) or 6-18 (rabbits) of gestation There are also methods which use different food combinations and especial diets to maximum the chance of having a baby with specific sex. The old believe is that eating salty, savory foods leads to delivering a boy and calcium rich foods to a girl. Some believes that the ratio of the minerals sodium, potassium, calcium and magnesium are important in determination of baby gender. It was shown that pregnant female house mice maintained on a consistent low-food diet give birth to a lower proportion of males than do control females fed ad libitum agreement with (E Dahl, 2003; de Blas, and Wiseman, 2003). we studied the Role of Sodium and Potassium ions in identification of offspring reported that(S Chandraju et al., 2011). 


\section{International Journal of Science and Research (IJSR) \\ ISSN (Online): 2319-7064}

Index Copernicus Value (2015): 78.96 | Impact Factor (2015): 6.391

Table 3.2: Change in blood biochemistry parameters in pregnant Rabbits. Mean \pm S.D

\begin{tabular}{|c|c|c|c|c|c|}
\hline Groups & No & $\begin{array}{c}\text { Sodium } \\
\mathrm{Na} \mu \mathrm{mol} / \mathrm{L}\end{array}$ & $\begin{array}{c}\text { Potassium } \\
\mathrm{K} \mu \mathrm{mol} / \mathrm{L}\end{array}$ & $\begin{array}{c}\text { Magnesium } \\
\mathrm{Mg} \mu \mathrm{mol} / \mathrm{L}\end{array}$ & $\begin{array}{c}\text { Calcium } \\
\mathrm{Ca} \mu \mathrm{mol} / \mathrm{L}\end{array}$ \\
\hline Control & 5 & $142.60 \pm 1.14 \mathrm{~A}$ & $1.15 \pm 0.04 \mathrm{~B}$ & $0.84 \pm 0.06 \mathrm{~B}$ & $3.57 \pm 0.04 \mathrm{~B}$ \\
\hline$(\mathrm{Na}, \mathrm{K})$ & 5 & $151.80 \pm 2.04 \mathrm{~A}$ & $3.01 \pm 0.7 \mathrm{~A}$ & $0.60 \pm 0.17 \mathrm{C}$ & $3.14 \pm 0.13 \mathrm{C}$ \\
\hline$(\mathrm{Ca}, \mathrm{Mg})$ & 5 & $108.80 \pm 15.27 \mathrm{~B}$ & $1.10 \pm 0.06 \mathrm{~B}$ & $1.11 \pm 0.11 \mathrm{~A}$ & $4.68 \pm 0.39 \mathrm{~A}$ \\
\hline
\end{tabular}

\section{References}

[1] Arm and Hammer Baking soda(2009): Armandhammer.com. Retrieved, 07-30.

[2] Bradley, M. P.; Forrester, I. T., and Heslop, B. F. (1987): Identification of a male specific (H-Y) antigen on the flagellar plasma membrane of ram epididyrnal spermatozoa. Hum. Genet. 75, 362-7.

[3] Bolet , G.;L.Gueguen, P.;Dando and Ollivier, (1982): Influence of mineral diet of the sow on the sex ratio of the newborn .Reprod.Nutr.Dev., 22:1073-1081.

[4] Baroiller J.F. and D'Cotta H., (2001): Environment and sex determination in farmed fish, Comp. Biochem. Physiol., 130: 399-409.

[5] Brannigan RE and Lipshultz LI(2008):Sperm Transport and Capacitation. Glob Libr Women's Med. Available from:http://www.glowm.com/index.

[6] Boiti C.( 2004): Underlying physiological mechanisms controlling the reproductive axis of rabbit does. In Proc.: 8th World Rabbit Congress, September 7-10, Puebla, Mexico, 186-206.

[7] Berepudo N.A.; Nodu M.B.; Monsi A. and Amadi E.N. (1993): Reproductive response of prepubertal female rabbit to photoperiod and/or male presence. World Rabbit Sci., 2, 83- 87.

[8] de Blas, C.and Wiseman, J. (2003): The Nutrition of the Rabbit. CABI Publishing, Oxon, UK.

[9] E Dahl, (2003): Procreative Liberty. The Case for Preconception Sex Selection.7Reproductive BioMedicine, 380.

[10] Eggert C., (2004): Sex determination: the amphibian models, Reprod. Nutr. Dev., 44: 539-549.

[11] Fregly MJ.(1981): Sodium and potassium. Annual review of nutrition, 1:69-93.

[12] Gottlieb, S., (2001):Us doctors say sex selection acceptable for non-medical reasons.BMJ., 323:828.

[13] Jequier AM, (2006): Sperm transport in the human and mammalian cervix and genital tract: its relation to fertility. In: Jordan JA, Singer A, editors. TheCervix. 2nd ed. Oxford: Blackwell Publishing Ltd; p. 169-80.

[14] Kracow, S. and P.S. Burgoyne, (1997):Timing of mating development asynchrony and the sex ratio in mice.Physiol.Behav., 63:81-84.

[15] Kelly KG.(1990): Tests on vaginal discharge. In:Walker HK, Hall WD, Hurst JW, editors. Clinical Methods: The History, Physical, and Laboratory Examinations. 3rd ed. Boston: Butterworths; p. 833-5. Acad. Sci. USA 70, 1502-5.

[16] Lepargneur JP and Rousseau V. Ro ${ }^{\wedge}$ le (2002):protecteur de la flore de Doderlei“n. J Gynecol Obstet Biol Reprod (Paris). 2002;3(5):485-94.

[17] Mousa-Balabel, T.M. (2004): Effect of heat stress on New Zealand White rabbits' behaviour and performance. Minufiya vet .J. vol . 3 NO. 1 April, 125134.
[18] Noguchi, K.;Tsukumi, K and Urano, T., (2003): Qualitative and quantitative differences in normal vaginal flora of conventionally reared mice, rats, hamsters, rabbits, and dogs. Comp Med., 53:404-12.

[19] Orcutt, JA. "Scientist".(2012): Pharmacology and Toxicology of Uranium Compounds. McGraw-Hill. Retrieved 21 March.

[20] Roseli J.M.(2000): Gestation extrauterina .In Enfermedades del conejo.Tomo II Enfermedades.(Edit.Rosell, j.M), Mundi-Prensa, PP.93.

[21] Roy S.;Caillouete JC.; Roy T and Faden JS.(2004): Vaginal $\mathrm{pH}$ is similar to folliclestimulating hormone for menopause diagnosis. Am J Obstet Gynecol. 190(5):1272-7.

[22] Suarez SS. and Pacey AA.(2006): Sperm transport in the female reproductive tract. Hum Reprod Update. 12(1):23-37.

[23] Sharif K, and Olufowobi O.(2006): The structure, chemistry and physics of humanncervical mucus. In: Jordan JA, Singer A, editors. The Cervix. 2nd ed.Oxford: Blackwell Publishing Ltd; p. 157-68.

[24] Wakim, P.E. (1972): Determining the sex of baby rabbits by ascertaining the $\mathrm{pH}$ of the vagina of the mother before mating. J. American Osteopathic Association, 72: 173-174 